University of Nebraska - Lincoln

DigitalCommons@University of Nebraska - Lincoln

1984

\title{
Ecological Distribution and Crude Density of Breeding Birds on Prairie Wetlands
}

\author{
Harold A. Kantrud \\ USGS Northern Prairie Wildlife Research Center \\ Robert E. Stewart \\ USGS Northern Prairie Wildlife Research Center
}

Follow this and additional works at: https://digitalcommons.unl.edu/usgsnpwrc

Part of the Other International and Area Studies Commons

Kantrud, Harold A. and Stewart, Robert E., "Ecological Distribution and Crude Density of Breeding Birds on Prairie Wetlands" (1984). USGS Northern Prairie Wildlife Research Center. 180.

https://digitalcommons.unl.edu/usgsnpwrc/180

This Article is brought to you for free and open access by the US Geological Survey at DigitalCommons@University of Nebraska - Lincoln. It has been accepted for inclusion in USGS Northern Prairie Wildlife Research Center by an authorized administrator of DigitalCommons@University of Nebraska - Lincoln. 


\title{
ECOLOGICAL DISTRIBUTION AND CRUDE DENSITY OF BREEDING BIRDS ON PRAIRIE WETLANDS
}

HAROLD A. KANTRUD, U.S. Fish and Wildlife Service, Northern Prairie Wildlife Research Center, Jamestown, ND 58401 ROBERT E. STEWART, U.S. Fish and Wildlife Service, Northern Prairie Wildlife Research Center, Jamestown, ND 58401

\begin{abstract}
Breeding populations of 28 species of wetland-dwelling birds other than waterfowl (Anatidae) were censused on 1,321 wetlands lying within the prairie pothole region of North Dakota. Ecological distribution and two crude measures of relative density were calculated for the 22 commonest species using eight wetland classes. Semipermanent wetlands supported nearly two-thirds of the population and were used by all 22 species, whereas seasonal wetlands contained about one-third of the population and were used by 20 species. Semipermanent, fen, and temporary wetlands contained highest bird densities on the basis of wetland area; on the basis of wetland unit, densities were highest on semipermanent, permanent, alkali, and fen wetlands. The highest ranking of semipermanent wetlands by all three measures of use was probably because these wetlands, as well as being relatively numerous and large, were vegetatively diverse. The fairly large proportion of the bird population supported by seasonal wetlands was a result of wetland abundance and moderate vegetative diversity. Increased vegetative diversity results from the development of characteristic zones of hydrophytes at sites where water persists longer during the growing season. Frequent cultivation of prairie wetlands results in the replacement of tall, robust perennials by bare soil or stands of short, weakstemmed annuals that likely are unattractive to nesting birds.
\end{abstract}

J. WILDL. MANAGE. 48(2):426-437

Approximately $39 \%$ of the 353 valid species on the North Dakota bird list (Faanes and Stewart 1982) use wetlands. Of the 223 species with known or inferred breeding status in the state, nearly $26 \%$ are marsh or aquatic birds other than waterfowl (Anatidae). Little information on the wetland habitats used by this large and important group of birds is available. Public works projects, construction related to energy production, private drainage schemes, and uncontrolled soil erosion continue to deplete and degrade habitat for wildlife in North Dakota. Therefore, it is important that the habitat required by these birds be more clearly defined if we are to ascertain the impact of losses and properly manage remaining habitats. Here we report the ecological distribution and density of some of the common species that breed in natural wetland basins in the prairie pothole region of North Dakota and provide a brief discussion of some of the basic factors believed responsible for the patterns of use observed among the wetland classes.

We thank D. W. Larson and C. R. Madsen who assisted with the general fieldwork in 1965 and G. L. Krapu who reviewed the manuscript.

\section{WETLAND HABITAT}

The system used to classify wetlands during this study (Stewart and Kantrud 1971) was developed specifically for the prairie pothole region of south-central Canada and north-central United States. Unlike the systems of Shaw and Fredine (1956) and Cowardin et al. (1979), which essentially classify various vegetated or nonvegetated areas or zones of wetland, the system of Stewart and Kantrud (1971) classifies entire basins which may contain one or more vegetative zones. In this system, the following five basic classes are distinguished on the basis of water permanence (degree of water retention) as indicated by the vegetative zone occupy- 
ing the central or deepest part of the wetland basin: ephemeral, temporary, seasonal, semipermanent, and permanent. Special classes include alkali, characterized by the intermittent occurrence of shallow, hypersaline surface water, and fen, recognized by a characteristic zone of fen vegetation that develops on areas containing surficial exposures of alkaline groundwater.

In North Dakota, many ephemeral, temporary, and seasonal wetlands are tilled for agricultural purposes. This presents problems for wetland classification. Cultivation in and around ephemeral wetlands usually results in soil movement and siltation which virtually eliminates these wetlands. Tilled temporary and seasonal wetlands often could not be assigned to their respective basic classes because plant species which would differentiate the classes were not present. Wetlands of this type were designated as undifferentiated tillage wetlands.

\section{METHODS}

Bird censuses were conducted in conjunction with waterfowl studies in the prairie pothole region of North Dakota (Fig. 1) during 1965, 1968, and 1969. Water levels in the wetlands were about average in 1965, below average in 1968, and above average in 1969. Bird censuses on dry wetlands are not included in this report. In 1965, data were obtained from wetlands selected subjectively in Stutsman and Kidder counties. These were uncommon classes of wetlands not found in sufficient amounts by later sampling. During 1968 , data were gathered from wetlands lying within 194 quarter-section (64.7 ha) sample plots selected at random within the entire prairie pothole region. In 1969, censuses were restricted to the southwestern portion of the region. Random cluster

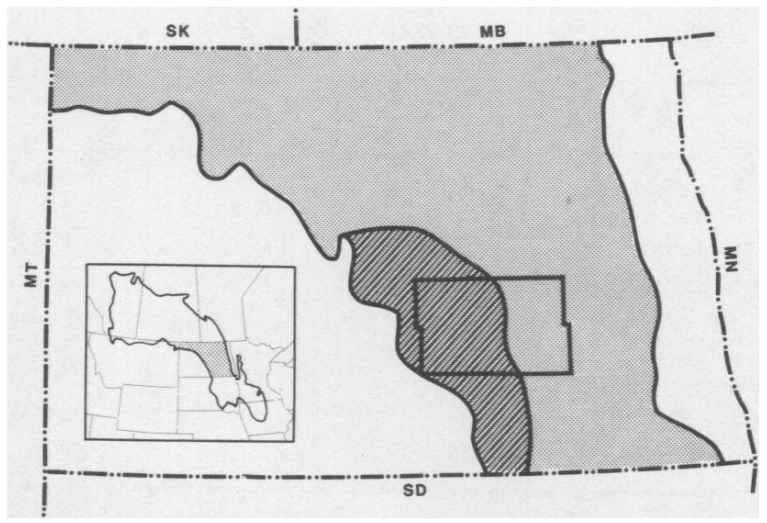

Fig. 1. Distribution of the prairie pothole region in North America (inset) and North Dakota. All of the region in North Dakota was sampled in 1968; only the diagonally hatched portion was sampled in 1969. Rectangular area shows border of Stutsman and Kidder counties where information from subjectively selected wetlands was gathered in 1965.

sampling was used in 1969; each cluster consisted of four quarter sections that formed the corners of a square with dimensions of $3.2 \times 3.2 \mathrm{~km}$. The total 1969 sample contained 120 quarter sections grouped as 30 clusters. Procedures used to stratify the region, determine sample sizes, and select sample units have been described previously (Stewart and Kantrud 1972 , 1973). Information from 1,321 wetlands containing water, with a total area of $23.25 \mathrm{~km}^{2}$, is included in this report (Table 1).

Censuses were conducted by two observers between 0.5 hours after sunrise and 0.5 hours before sunset when sustained wind velocities did not exceed $25 \mathrm{~km} /$ hour. On the quarter-section plots, each observer censused birds on a rectangular half of the sample unit. Each observer tried to avoid flushing birds on wetlands within his half of the sample unit. However, at the end of each census it was necessary to compare notes on birds flushed to avoid duplications in the counts. During censuses of large wetlands, one observer counted birds from a high vantage 
Table 1. Number and area of wetlands censused."

\begin{tabular}{lrcccc}
\hline \multicolumn{1}{c}{ Wetland class } & $N$ & $\%$ & $\begin{array}{c}\text { Area } \\
\left(\mathrm{km}^{2}\right)\end{array}$ & $\%$ & $\begin{array}{c}\text { Mean area } \\
(\text { ha })\end{array}$ \\
\hline Ephemeral & 4 & $<1$ & $\operatorname{tr}^{\mathrm{b}}$ & $<1$ & 0.025 \\
Temporary & 190 & 14.4 & 0.199 & $<1$ & 0.10 \\
Seasonal & 808 & 61.2 & 5.25 & 22.6 & 0.65 \\
Semipermanent & 168 & 12.7 & 6.58 & 28.3 & 3.92 \\
Permanent & 14 & 1.0 & 6.23 & 26.8 & 44.5 \\
Alkalic & 8 & $<1$ & 4.46 & 19.2 & 55.8 \\
Fenc & 11 & $<1$ & 0.409 & 1.8 & 3.72 \\
Undifferentiated tillage & 118 & 8.9 & 0.123 & $<1$ & 0.10 \\
\multicolumn{1}{c}{ Totals } & 1,321 & 100 & 23.25 & 100 & \\
\hline
\end{tabular}

a Maximum number and acreage of wetlands with surface water.

$\mathrm{b}_{\mathrm{tr}}=<0.05 \mathrm{~km}^{2}$.

c Figures include 11 permanent, 5 fen, and 4 alkali wetlands nonrandomly selected and censused during 1965; all other wetlands censused during random sample surveys conducted in 1968 and 1969.

point while the other observer flushed and counted birds while wading a zigzag course through the wetland. Counts were based primarily on numbers of indicated pairs during peak breeding periods. The highest number of indicated pairs was always selected when more than one count was available for a species within its peak breeding period.

Indicated "pairs" of red-winged (Agelaius phoeniceus) and yellow-headed (Xanthocephalus xanthocephalus) blackbirds were based on observed territorial males, even though many more females were present. Each male or female northern harrier (Circus cyaneus) observed was considered to represent a pair unless birds of both sexes were seen on a single wetland. Density estimates of the pied-billed grebe (Podilymbus podiceps) and rails (Rallidae) are probably low due to their silent, secretive behavior and their reluctance to flush from heavy cover. Colonialnesting species (e.g., white pelican [Pelecanus erythrorhynchos], double-crested cormorant [Phalacrocorax auritus], and gulls [Laridae]) that used the wetlands but nested elsewhere were not counted.

The chronology of censuses was adjusted slightly each year to compensate for variable phenological conditions. In 1965 each wetland was censused once during 5-16 May and again during 7-24 June. In 1968 wetlands were censused 23 April-15 July. Each wetland was censused once or twice. Wetlands censused once were those visited 15 May-7 June. Censuses conducted 23 April-7 June were considered valid for killdeer (Charadrius vociferus), an early-nesting species. Estimates of indicated pairs of mid-nesting species were derived from wetlands censused 15 May15 July. Species considered mid-nesters were northern harrier, Virginia rail (Rallus limicola), sora (Porzana carolina), American coot (Fulica americana), piping plover (Charadrius melodus), willet (Catoptrophorus semipalmatus), marbled godwit (Limosa fedoa), American avocet (Recurvirostra americana), Wilson's phalarope (Phalaropus tricolor), black tern (Chlidonias niger), yellow-headed blackbird, red-winged blackbird, and savannah sparrow (Passerculus sandwichensis). Censuses conducted 22 May-15 July were used to estimate breeding pairs of latenesting species including horned grebe (Podiceps auritus), eared grebe (P. nigricollis), western grebe (Aechmophorus occidentalis), pied-billed grebe, blackcrowned night-heron (Nycticorax nycticorax), American bittern (Botaurus len- 
Table 2. Distribution (\%) of breeding birds among classes of wetlands. ${ }^{a}$

\begin{tabular}{|c|c|c|c|c|c|c|c|c|c|}
\hline \multirow[b]{2}{*}{ Species } & \multirow[b]{2}{*}{$\begin{array}{c}\text { Pairs } \\
\text { in sample } \\
N\end{array}$} & \multicolumn{8}{|c|}{ Wetland class } \\
\hline & & $\begin{array}{l}\text { Ephem- } \\
\text { eral }\end{array}$ & $\begin{array}{c}\text { Tempo- } \\
\text { rary }\end{array}$ & Seasonal & $\begin{array}{c}\text { Semiper- } \\
\text { manent }\end{array}$ & $\begin{array}{c}\text { Per- } \\
\text { manent }\end{array}$ & Alkali & Fen & $\begin{array}{c}\text { Undiffer- } \\
\text { entiated } \\
\text { tillage }\end{array}$ \\
\hline Horned grebe & 11 & & & 64 & 36 & & & & \\
\hline Eared grebe & 35 & & & 54 & 34 & 11 & & & \\
\hline Western grebe & 20 & & & & 5 & 95 & & & \\
\hline Pied-billed grebe & 111 & & & 23 & 68 & 7 & & 1 & \\
\hline Black-crowned night-heron & 36 & & & 6 & 75 & 19 & & & \\
\hline American bittern & 54 & & 2 & 30 & 69 & & & & \\
\hline Northern harrier & 13 & & & 23 & 77 & & & & \\
\hline Virginia rail & 14 & & & 14 & 86 & & & & \\
\hline Sora & 154 & & 1 & 45 & 54 & & & & \\
\hline American coot & 1,648 & & $\operatorname{tr}^{b}$ & 24 & 72 & 4 & & & \\
\hline Killdeer & 51 & & 4 & 53 & 39 & 4 & & & \\
\hline Willet & 118 & & 2 & 56 & 39 & 3 & 1 & & \\
\hline Marbled godwit & 65 & & 3 & 57 & 37 & & 3 & & \\
\hline American avocet & 45 & & & 38 & 47 & & 9 & & 7 \\
\hline Wilson's phalarope & 257 & & 4 & 60 & 30 & & 4 & $\operatorname{tr}$ & 3 \\
\hline Black tern & 410 & & $\operatorname{tr}$ & 25 & 72 & 2 & & $\operatorname{tr}$ & \\
\hline Marsh wren & 193 & & & 9 & 91 & & & & \\
\hline Common yellowthroat & 60 & & & 48 & 52 & & & & \\
\hline Yellow-headed blackbird & 1,104 & & $\operatorname{tr}$ & 6 & 94 & & & & \\
\hline Red-winged blackbird & 1,245 & $\operatorname{tr}$ & 2 & 61 & 35 & 1 & $\operatorname{tr}$ & $\operatorname{tr}$ & \\
\hline Savannah sparrow & 167 & 1 & 10 & 49 & 38 & & 1 & 1 & \\
\hline Total birds & 5,811 & $\operatorname{tr}$ & 1 & 33 & 63 & 2 & $\operatorname{tr}$ & $\operatorname{tr}$ & $\operatorname{tr}$ \\
\hline
\end{tabular}

a Data from wetlands censused during random sample surveys, 1968-69.

$\mathrm{b}_{\mathrm{tr}}=<0.5 \%$.

tiginosus), marsh wren (Cistothorus palustris), and common yellowthroat (Geothlypis trichas). In 1969, a single census was conducted during 20 May-10 June.

Data were not included for species represented in the count totals by fewer than 10 pairs. These included the red-necked grebe (Podiceps grisegena), spotted sandpiper (Actitis macularia), sedge wren (Cistothorus platensis), Le Conte's sparrow (Ammodramus leconteii), sharptailed sparrow (A. caudacutus), song sparrow (Melospiza melodia), and swamp sparrow (M. georgiana).

\section{RESULTS}

The data on ecological distribution of breeding populations of 21 species (Table 2) were obtained by random sampling and thus assess the relative use of the various wetland classes by populations of each species. (Note: piping plover, the 22nd species, did not occur on this sample of wetlands.) Seasonal and semipermanent wetlands provided habitat for the largest proportion of the population of all species except the western grebe which was found mostly in permanent lakes. Nearly twothirds of the total population were found on semipermanent wetlands. All 21 species were found in semipermanent wetlands; for 11 species, over half of the population was found on them. Seasonal wetlands were used by 20 species and supported about one-third of the total censused population. From 53 to $64 \%$ of the population of seven species occupied these wetlands. Ephemeral, temporary, alkali, and undifferentiated tillage wetlands were of little importance to the birds listed.

Among species, the Wilson's phalarope, 
Table 3. Density of breeding birds among classes of wetlands."

\begin{tabular}{|c|c|c|c|c|c|c|c|c|c|}
\hline \multirow[b]{2}{*}{ Species } & \multirow[b]{2}{*}{$\begin{array}{c}\text { Pairs } \\
\text { in sample } \\
N\end{array}$} & \multicolumn{8}{|c|}{ Wetland class } \\
\hline & & Ephemeral & Temporary & Seasonal & $\begin{array}{l}\text { Semiper- } \\
\text { manent }\end{array}$ & Permanent & Alkali & Fen & $\begin{array}{l}\text { Undiffer- } \\
\text { entiated } \\
\text { tillage }\end{array}$ \\
\hline Horned grebe & 13 & & & $\begin{array}{l}1.4 \\
(0.01)\end{array}$ & $\begin{array}{l}0.6 \\
(0.03)\end{array}$ & $\begin{array}{l}0.3 \\
(0.15)\end{array}$ & & & \\
\hline Eared grebe & 42 & & & $\begin{array}{l}3.9 \\
(0.03)\end{array}$ & $\begin{array}{l}1.9 \\
(0.10)\end{array}$ & $\begin{array}{l}1.6 \\
(0.15)\end{array}$ & & & \\
\hline Western grebe & 20 & & & & $\begin{array}{l}0.2 \\
(0.01)\end{array}$ & $\begin{array}{l}2.8 \\
(1.47)\end{array}$ & & & \\
\hline Pied-billed grebe & 116 & & & $\begin{array}{l}5.4 \\
(0.04)\end{array}$ & $\begin{array}{l}11.9 \\
(0.62)\end{array}$ & $\begin{array}{l}1.3 \\
(0.70)\end{array}$ & & $\begin{array}{l}12.2 \\
(0.57)\end{array}$ & \\
\hline Black-crowned night-heron & 43 & & & $\begin{array}{l}0.4 \\
t^{b}\end{array}$ & $\begin{array}{c}4.2 \\
(0.22)\end{array}$ & $\begin{array}{l}1.0 \\
(0.54)\end{array}$ & & $\begin{array}{l}17.2 \\
(0.80)\end{array}$ & \\
\hline American bittern & 58 & & $\begin{array}{l}5.8 \\
(0.01)\end{array}$ & $\begin{array}{l}3.3 \\
(0.02)\end{array}$ & $\begin{array}{l}5.8 \\
(0.30)\end{array}$ & $\begin{array}{c}0.1 \\
(0.08)\end{array}$ & & $\begin{array}{l}8.4 \\
(0.34)\end{array}$ & \\
\hline Northern harrier & 16 & & & $\begin{array}{l}0.6 \\
\operatorname{tr}\end{array}$ & $\begin{array}{l}1.5 \\
(0.08)\end{array}$ & & & $\begin{array}{l}7.5 \\
(0.38)\end{array}$ & \\
\hline Virginia rail & 17 & & & $\begin{array}{l}0.4 \\
\operatorname{tr}\end{array}$ & $\begin{array}{l}1.8 \\
(0.09)\end{array}$ & & & $\begin{array}{l}7.5 \\
(0.38)\end{array}$ & \\
\hline Sora & 165 & & $\begin{array}{l}10.1 \\
(0.01)\end{array}$ & $\begin{array}{l}12.9 \\
(0.09)\end{array}$ & $\begin{array}{l}12.6 \\
(0.62)\end{array}$ & & $\begin{array}{l}0.2 \\
(0.16)\end{array}$ & $\begin{array}{l}25.1 \\
(1.28)\end{array}$ & \\
\hline American coot & 1,671 & & $\begin{array}{l}25.2 \\
(0.03)\end{array}$ & $\begin{array}{l}73.8 \\
(0.51)\end{array}$ & $\begin{array}{c}180.5 \\
(8.96)\end{array}$ & $\begin{array}{c}8.9 \\
(4.67)\end{array}$ & & $\begin{array}{l}52.8 \\
(2.69)\end{array}$ & \\
\hline Piping plover & 11 & & & & $\begin{array}{c}0.2 \\
(0.01)\end{array}$ & & $\begin{array}{l}2.2 \\
(1.61)\end{array}$ & & \\
\hline Killdeer & 65 & & $\begin{array}{l}20.6 \\
(0.02)\end{array}$ & $\begin{array}{l}7.2 \\
(0.06)\end{array}$ & $\begin{array}{l}5.3 \\
(0.24)\end{array}$ & $\begin{array}{l}1.2 \\
(0.64)\end{array}$ & $\begin{array}{l}2.0 \\
(1.82)\end{array}$ & & \\
\hline Willet & 128 & & $\begin{array}{l}10.1 \\
(0.01)\end{array}$ & $\begin{array}{l}12.3 \\
(0.08)\end{array}$ & $\begin{array}{l}7.0 \\
(0.35)\end{array}$ & $\begin{array}{l}1.0 \\
(0.54)\end{array}$ & $\begin{array}{l}1.3 \\
(0.97)\end{array}$ & $\begin{array}{l}2.5 \\
(0.13)\end{array}$ & \\
\hline Marbled godwit & 78 & & $\begin{array}{l}10.1 \\
(0.01)\end{array}$ & $\begin{array}{l}6.9 \\
(0.05)\end{array}$ & $\begin{array}{l}3.6 \\
(0.18)\end{array}$ & $\begin{array}{l}0.1 \\
(0.08)\end{array}$ & $\begin{array}{l}2.7 \\
(1.94)\end{array}$ & $\begin{array}{l}5.0 \\
(0.26)\end{array}$ & \\
\hline American avocet & 128 & & & $\begin{array}{c}3.2 \\
(0.02)\end{array}$ & $\begin{array}{l}3.2 \\
(0.16)\end{array}$ & & $\begin{array}{l}19.5 \\
(14.03)\end{array}$ & & $\begin{array}{l}26.8 \\
(0.03)\end{array}$ \\
\hline Wilson's phalarope & 269 & & $\begin{array}{l}45.4 \\
(0.05)\end{array}$ & $\begin{array}{l}28.9 \\
(0.20)\end{array}$ & $\begin{array}{l}11.5 \\
(0.57)\end{array}$ & $\begin{array}{l}0.1 \\
(0.08)\end{array}$ & $\begin{array}{c}4.3 \\
(3.06)\end{array}$ & $\begin{array}{c}5.0 \\
(0.26)\end{array}$ & $\begin{array}{l}62.5 \\
(0.06)\end{array}$ \\
\hline Black tern & 428 & & $\begin{array}{l}5.8 \\
(0.01)\end{array}$ & $\begin{array}{l}19.0 \\
(0.13)\end{array}$ & $\begin{array}{l}44.9 \\
(2.23)\end{array}$ & $\begin{array}{l}3.3 \\
(1.70)\end{array}$ & & $\begin{array}{l}17.2 \\
(0.80)\end{array}$ & \\
\hline Marsh wren & 212 & & & $\begin{array}{c}4.9 \\
(0.04)\end{array}$ & $\begin{array}{l}43.8 \\
(2.61)\end{array}$ & & & $\begin{array}{l}52.6 \\
(2.71)\end{array}$ & \\
\hline
\end{tabular}




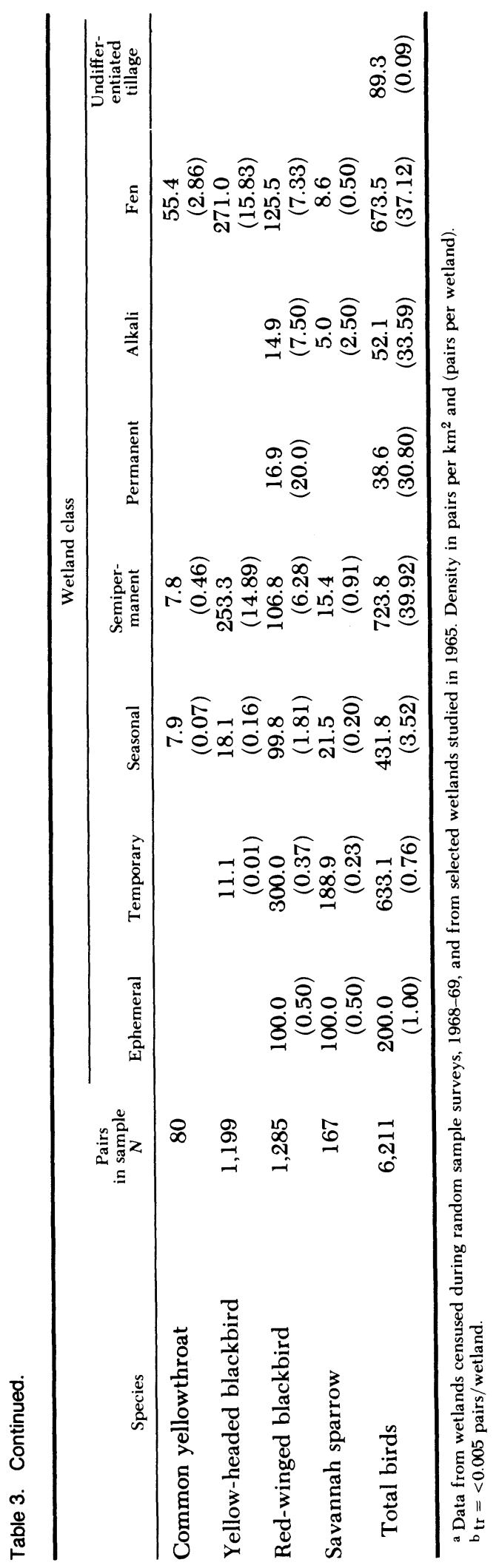

red-winged blackbird, and savannah sparrow were found in nearly all (six or seven) of the eight wetland classes. These species generally occupy the peripheral low prairie and wet meadow areas of most classes of wetlands. Six species, including the horned grebe, western grebe, northern harrier, Virginia rail, marsh wren, and common yellowthroat, were restricted to only two wetland classes. These species usually nest over water or in the tall or dense emergent vegetation found in the central zones of wetlands. The narrowest habitat requirements were shown by the western grebe, marsh wren, and yellowheaded blackbird. For these, over $90 \%$ of the population recorded occurred on a single wetland class.

Densities are expressed in pairs per $\mathbf{~ k m}^{2}$ and pairs per wetland in Table 3 . These are crude measures of density because they are based on the entire wetland, rather than on specific zones or plant communities used by the birds. On the basis of wetland area, highest densities of birds occurred on the semipermanent class. These wetlands supported peak densities of American coot and black tern. Fens were second in total bird density and were especially well used by the pied-billed grebe, black-crowned night-heron, American bittern, northern harrier, Virginia rail, sora, marsh wren, common yellowthroat, and yellow-headed blackbird. Temporary wetlands ranked third in total bird density due primarily to high densities of redwinged blackbirds and savannah sparrows. Killdeer and marbled godwit were also found in greatest densities on these wetlands although most of the use was of shoreline areas. Seasonal wetlands supported highest densities of horned and eared grebe and willet, but only moderate densities of most other species.

Other wetland classes had low total densities, but were highly attractive to 
several individual species. The permanent class was highly utilized by the western grebe and alkali wetlands supported peak densities of the piping plover. Agricultural use of wetlands obviously decreased their value to most species except for the American avocet and Wilson's phalarope which reached highest densities on wetlands with frequently tilled soils.

Breeding bird densities expressed on a pairs-per-wetland-unit basis (Table 3 ) show the important effects of wetland size on the number of birds supported by an average wetland of each class. On this basis, the average number of pairs on semipermanent, permanent, alkali, and fen wetlands was generally high. These were the largest-sized wetlands (Table 1). The remaining classes contained small numbers of birds on a pairs-per-wetland basis; corresponding sizes of these wetlands were small.

Fens contained the greatest average number of pairs per wetland of blackcrowned night-heron, American bittern, northern harrier, Virginia rail, sora, marsh wren, common yellowthroat, and yellowheaded blackbird. Alkali wetlands supported the most piping plover, killdeer, willet, marbled godwit, American avocet, Wilson's phalarope, and savannah sparrow, whereas largest numbers of all four species of grebe and red-winged blackbird were found in permanent wetlands. Semipermanent wetlands supported peak numbers of only two species, the American coot and black tern.

\section{DISCUSSION}

It is beyond the scope of this paper to discuss the effects of the large number of environmental variables that influence the density and ecological distribution of this diverse group of birds. Water permanence forms the basis for classification of most of the wetland types here considered and our discussion will be mostly limited to that factor, especially as it relates to the occurrence of zones of marsh and aquatic plants that comprise the nesting substrate for most bird species studied.

The information presented on densities expressed in pairs per $\mathrm{km}^{2}$ and pairs per wetland provides only crude measures of the relative attractiveness of the various wetland classes. Such information must be used with caution, and use of these data to estimate potential populations on small blocks of land is to be avoided because wetlands of all classes vary considerably in size and water-retention capability (Kantrud and Stewart 1977). Some wetland classes also vary greatly in water chemistry and economic use. This also may profoundly influence the structure and species composition of the vegetative substrate used by birds.

Although a general correlation exists between average water depth and water permanence among ephemeral, temporary, seasonal, and semipermanent wetlands, the differences in average depth at the beginning of the ice-free period may be only a few decimeters (Kantrud and Stewart 1977). Much greater differences in depth occur later in the growing season because of the great variation in rate of water loss among the classes. Thus, during a median year (water levels were higher in 2 years and lower in 3), dates of drying for ephemeral, temporary, and seasonal wetlands were about 1 May, 1 June, and 1 October, whereas the semipermanent wetlands still contained water at freezeup (Kantrud and Stewart 1977).

Corresponding differences are evident in the plant communities that have adapted to the environmental conditions found in these wetlands (Stewart and Kantrud 1971). In all but ephemeral wetlands, these communities occur within concentric zones peripheral to a central zone of 
greatest water permanence. Vegetation in the central zone also is characteristic. In semipermanent wetlands, the central deep-marsh zone is dominated by communities of tall robust emergents that may be interspersed with beds of submerged aquatics. Outside the deep-marsh zone lies a shallow-marsh zone dominated by sparser plants of medium height and a few subdominant submerged aquatics. A zone of wet meadow occurs farther shoreward, which does not support submerged plants and is dominated by shorter junciform species. Finally, a low-prairie zone bordering the uplands may be found. This zone is usually dominated by relatively short grasses and forbs. In semipermanent wetlands, all four zones are usually represented. In seasonal wetlands, the shallow marsh is central, and so on, until in ephemeral wetlands only the low-prairie zone is present. Thus, as water permanence increases, more morphologically and ecologically varied plant communities are represented.

Therefore, even without the natural disturbances wrought by fire and grazing, both horizontal and vertical habitat heterogeneity increases with water permanence on most types of prairie wetlands. Increased water permanence also results in a greater variety of invertebrates, unless shorelines are abrupt and the concentric zones of vegetation absent or exceedingly narrow (G. A. Swanson, pers. commun.). However, these generalizations cannot be extended to include permanent wetlands, the only other wetlands here classified on the basis of water permanence. The central open-water zone of permanent wetlands is usually deep and large, and unless permanent wetlands contain protected bays or are very small, wind and wave action precludes the establishment of extensive stands of emergent vegetation. Emergent vegetative zones are often absent on permanent wetlands; instead, the shorelines are composed of boulders, cobbles, pebbles, or sand. Productivity of permanent wetlands may increase during drought as annual plant species germinate on exposed bottom soils and shallow water areas form along receding shorelines.

Alkali and fen wetlands often maintain water for extended periods during drought; surprisingly, groundwater seepage into these wetlands may actually increase during drought. This likely reflects a time lag that results from the slow movement of groundwater from regional topographic highs to topographic lows after much earlier precipitation (Winter and Carr 1980).

References to total density of breeding birds other than waterfowl on wetlands in the prairie pothole region of North America are few. Very high densities (21 nests/ ha) were recorded on a 5.3-ha semipermanent wetland in Iowa (Provost 1947) which the author believed to be typical of small wetlands in the region. When water levels were low, extremely high densities (10-34 territorial males/ha) were also found by Krapu and Green (1978) in North Dakota on four small semipermanent wetlands. When water levels were higher, Krapu and Sorenson (1965) found five nests/ha on three large semipermanent wetlands in North Dakota and Krapu and Duebbert (1974) found 744 pairs $/ \mathrm{km}^{2}$ on a very large (350 ha) wetland in the southeastern corner of the state. The results of these two studies agree well with the 724 pairs $/ \mathrm{km}^{2}$ we found on semipermanent wetlands during our investigation.

Birds shift to more permanent wetland habitats during dry years. During Faanes' (1982 and pers. commun.) study, semipermanent, permanent, and alkali wetlands supported much higher breeding 
bird densities than we found. The pronounced shift of marbled godwit use from ephemeral and temporary to semipermanent wetlands during drought (Ryan 1982) illustrates this phenomenon. Whether such shifts result from a lack of water in less permanent wetlands, or the appearance during drought of a newly exploitable food resource in the more permanent wetlands, is unknown.

In South Dakota, Weber (1978) censused birds on wetlands lying within plots selected randomly. The results of Weber's study and ours may be compared if only the 10 bird species and five wetland classes common to both studies are considered. Both studies showed highest overall bird density on semipermanent wetlands, intermediate values for temporary and seasonal wetlands, and relatively little use of ephemeral and permanent wetlands. In addition, both studies showed that the greatest number of species occurred on seasonal and semipermanent wetlands. Species composition and relative abundance of the more common species of birds within the various wetland classes were also similar except for the red-winged blackbird, which attained higher densities in seasonal and semipermanent wetlands in South Dakota than in North Dakota. In contrast, higher densities were recorded for this species in ephemeral and temporary wetlands in North Dakota. These differences may be due, in part, to the effects of wetland size in the respective study areas; in North Dakota, the seasonal and semipermanent wetlands averaged much larger than those in South Dakota whereas the ephemeral and temporary wetlands were smaller. Open water or sparsely vegetated areas become more common as wetland size increases (Sugden 1977, 1979) due to the effects of wave action. These areas are not utilized by the red-winged blackbird. This explanation is supported by Weber's (1978) multiple regression analysis of the factors accounting for variation in the number of territorial male red-winged blackbirds found on semipermanent wetlands. He found that the percentage of open water had the highest negative correlation with the number of males, i.e., there was greater use of wetlands with large stands of emergent vegetation. However, reductions in pairs per unit area with increases in wetland size do not occur for all species. For example, Sugden (1979) has shown that, for the American coot, lack of interior cover on large wetlands may be compensated for by greater use of peripheral cover.

Weller and Spatcher (1965) and Weller and Fredrickson (1973) found that the greatest number of species occurred on semipermanent wetlands when a good interspersion of emergent cover and open water was present. Weber (1978) concluded that semipermanent wetlands, in particular, were characterized by relatively greater habitat diversity. Although we did not measure habitat diversity, the large number of species that we found on semipermanent wetlands (Table 1) fully supports these conclusions. We believe that, in semipermanent wetlands, the presence of several vegetative zones, each with a characteristic life form, creates a greater habitat diversity than that found on any of the other wetland classes. Each of these zones supports a characteristic nesting avifauna (Bent 1907, Stewart 1975) and may also be used by other species for other activities. Except for seasonal, permanent, and fen wetlands, which also had relatively high species diversity, probably because of the presence of at least three of the zones, other wetland classes contained only one or two zones and the number of bird species was correspondingly small. Among 
ephemeral and undifferentiated tillage wetlands, only a single zone was represented, and use by birds likely was severely limited by lack of habitat diversity. The rapid rate of water loss in these wetlands also precludes high utilization by most species.

The high value of semipermanent wetlands may also be revealed by comparing their relative abundance with the proportion of the total breeding bird population they support. These wetlands made up about $47 \%$ of the total area of wetland habitat in the random sample, but supported $63 \%$ of the total breeding birds (Table 2).

Seasonal wetlands attracted all the common birds except the western grebe. Although, on the basis of area, total bird density was only about $60 \%$ of that found on semipermanent wetlands, most of the difference was due to the large numbers of American coot and yellow-headed blackbirds found in the emergent deepmarsh zone of the semipermanent wetlands. Of the 20 species utilizing both types (Table 2), nearly half reached higher density on seasonal wetlands. This could be caused by the effects of wetland size as previously discussed and as illustrated by the data presented in Table 3, but the greater water fertility of seasonal wetlands could have been responsible. Swanson et al. (1974) have shown that nutrient availability remains high in seasonal wetlands because of the regularity with which organic matter is oxidized as these wetlands become dry during late summer. They also noted that temporary and seasonal wetlands produce invertebrates earlier in the season than semipermanent wetlands because of the more rapid warming of their shallow waters.

The deleterious effect of frequent cultivation of prairie wetlands on their use by birds is evident. During this study, undifferentiated tillage wetlands were used only by small numbers of killdeer, American avocet, and Wilson's phalarope. In 1967, these wetlands made up about $25 \%$ of the total wetland acreage in the prairie pothole region of North Dakota (Stewart and Kantrud 1973). Nutrient levels in tilled wetlands are undoubtedly very high due to regular oxidation of fertile bottom soils and additions from agricultural runoff. Although production of invertebrate food items, at least for waterfowl, can sometimes remain high in these wetlands if adequate amounts of crop stubble or other vegetative debris are available, present tillage methods generally provide a poor substrate for invertebrate production (Krapu 1974). Nevertheless, we believe the general unattractiveness of these wetlands is mostly due to lack of suitable nest sites for most species. When wetlands are thoroughly tilled and cropped during dry years, tall, strong-stemmed perennial plants are temporarily eliminated; when hydrophyte succession is resumed during wet years, the early stages favor short, weak-stemmed annuals which cannot support the nests of most bird species.

Although heavily used by a few species, ephemeral, temporary, permanent, alkali, and fen wetlands were of minor importance to most birds. Water is probably present in ephemeral and temporary wetlands for too short a period to support populations of aquatic food organisms or provide overwater nest sites throughout the breeding season. Permanent wetlands often are excessively deep, poorly vegetated, and contain fish populations that may compete with birds for invertebrate food items (Swanson and Nelson 1970). Alkali wetlands, though exceedingly nutrient rich, contain little or no emergent shoreline vegetation; this severely limits 
nesting opportunities. Fens were used by many species, but were relatively scarce; thus, their proportional contribution to the support of breeding bird populations was low.

With the exception of the Rallidae, all birds discussed in this paper are nongame species. The great overall value of seasonal and semipermanent wetlands shown here for nongame birds is paralleled by use of these wetlands by breeding waterfowl. For example, Kantrud and Stewart (1977) found $90.3 \%$ of the breeding waterfowl population in the prairie pothole region of North Dakota on seasonal and semipermanent wetlands. Similar high percentages of ducks use these types of wetlands in the parklands of Canada (Smith 1971, Stoudt 1971).

In conclusion, we believe tracts of grassland containing complexes of seasonal and semipermanent wetlands must be preserved in order to avoid drastic population declines among marsh-dwelling birds in North Dakota and other areas within the prairie pothole region. Both plant and animal species diversity will also be maintained if complexes containing some of the less common wetland classes are also protected, because such protection would allow organisms greater opportunity for successful reproduction, or at least maintenance of populations through the broad range of climatic conditions common to the prairies. It is important that the various vegetative zones of protected wetlands be managed to avoid the deleterious effects of either cultivation or idling. Burning or grazing or a combination of these two forces will be required to maintain wetlands in the best condition for most bird species. We have observed many instances where these forces seemed to benefit the productivity of prairie wetlands and their use by breeding and migrant birds. We suspect these benefits accrue because of decreases in the extent of monotypic stands of emergent vegetation and the creation of openings that allow insolation and greater biological productivity within shallow-water zones. In addition to the control of indiscriminate drainage and soil erosion, it is also important that reasonably nonexploitative landuse practices be maintained in areas where wetlands are protected in order that hydrological imbalances caused by excessive human withdrawals of groundwater can be avoided.

Finally, it must be stressed that this paper deals only with use by breeding birds. Wetlands in the prairie pothole region are also undoubtedly of great, but thus far little known, importance to many other avian species that make extensive use of these wetlands during both spring and fall migration.

\section{LITERATURE CITED}

BENT, A. C. 1907. The marbled godwit on its breeding grounds. Auk 24:160-167.

Cowardin, L. M., V. Carter, F. C. Golet, and E. T. LAROE. 1979. Classification of wetlands and deepwater habitats of the United States. U.S. Fish Wildl. Serv. Biol. Serv. Program FWS/OBS-79/ 31. 103pp.

FAANES, C. A. 1982. Avian use of Sheyenne Lake and associated habitats in central North Dakota. U.S. Fish Wildl. Serv. Resour. Publ. 144. 24pp. , AND R. E. STEWART. 1982. Revised checklist of North Dakota birds. Prairie Nat. 14:8192.

Kantrud, H. A., AND R. E. Stewart. 1977. Use of natural basin wetlands by breeding waterfowl in North Dakota. J. Wildl. Manage. 41:243-253.

KraPU, G. L. 1974. Feeding ecology of pintail hens during reproduction. Auk 91:278-290.

—, AND H. F. DUEBBERT. 1974. A biological survey of Kraft Slough. Prairie Nat. 6:33-55.

- AND R. K. GREEN. 1978. Breeding bird populations of selected semipermanent wetlands in south-central North Dakota-1977. Am. Birds 32:110-112.

$\longrightarrow$, AND M. Sorenson. 1965. 53. Bulrush marsh. 54. Cattail-bulrush marsh. 55. Cattail marsh. Audubon Field Notes 19:619-620.

Provost, M. W. 1947. Nesting of birds in the marshes of northwest Iowa. Am. Midl. Nat. 38: 485-503. 
Ryan, M. R. 1982. Marbled godwit habitat selection in the northern prairie region. Ph.D. Thesis, Iowa State Univ., Ames. 108pp.

Shaw, S. P., AND C. G. Fredine. 1956. Wetlands of the United States. U.S. Fish Wildl. Serv. Circ. 39. $67 \mathrm{pp}$.

SMITH, A. G. 1971. Ecological factors affecting waterfowl production in the Alberta parklands. U.S. Fish Wildl. Serv. Resour. Publ. 98. 49pp.

StewarT, R. E. 1975. Breeding birds of North Dakota. Tri-Coll. Cent. Environ. Stud., Fargo, N.D. 295pp.

, AND H. A. KanTrud. 1971. Classification of natural ponds and lakes in the glaciated prairie region. U.S. Fish Wildl. Serv. Resour. Publ. 92. $57 \mathrm{pp}$.

, AND 1972. Population estimates of breeding birds in North Dakota. Auk 89:766788.

- AND —. 1973. Ecological distribution of breeding waterfowl populations in North Dakota. J. Wildl. Manage. 37:39-50.

StoudT, J. H. 1971. Ecological factors affecting waterfowl production in the Saskatchewan parklands. U.S. Fish Wildl. Serv. Resour. Publ. 99. $58 \mathrm{pp}$.

SugDEN, L. G. 1977. Horned grebe breeding habitat in Saskatchewan parklands. Can. Field-Nat. 91:372-376.
1979. Habitat use by nesting American coots in Saskatchewan parklands. Wilson Bull. 91:599-607.

Swanson, G. A., M. I. MEYER, AND J. R. SERIE. 1974. Feeding ecology of breeding blue-winged teals. J. Wildl. Manage. 38:396-407.

, AND H. K. NELSON. 1970. Potential influence of fish rearing programs on waterfowl breeding habitat. Pages 65-71 in E. Schneberger, ed. A symposium on the management of midwestern winterkill lakes. Am. Fish. Soc., North Cent. Div., Winnipeg, Manit.

WEBER, M. J. 1978. Non-game birds in relation to habitat variation on South Dakota wetlands. M.S. Thesis, South Dakota State Univ., Brookings. $54 \mathrm{pp}$.

Weller, M. W., aNd L. H. Fredrickson. 1973. Avian ecology of a managed glacial marsh. Living Bird 12:269-291.

, AND C. S. Spatcher. 1965. Role of habitat in the distribution and abundance of marsh birds. Iowa State Univ. Exp. Stn. Spec. Rep. 43. 31pp.

Winter, T. C., AND M. R. CarR. 1980. Hydrologic setting of wetlands in the Cottonwood Lake study area, Stutsman County, North Dakota. U.S. Geol. Surv. Water-Resour. Invest. 80-99. 42pp.

Received 13 April 1983.

Accepted 17 August 1983. 